\title{
National Turbulence and the Turbos of the World Cinema System
}

\author{
Dudley Andrew \\ R. Selden Rose Professor of Film and Comparative Literature, Yale University, \\ New Haven, Connecticut, USA \\ dudley.andrew@yale.edu
}

\begin{abstract}
From the outset cinema was metropolitan. Producers needed access to financing, pools of talent, specialized equipment, and laboratories that one could only find in urban centers. In certain cinema-cities (Berlin, Paris, Buenos Aires, Mumbai, Taipei, etc.) reside ambitious writers, producers, and filmmakers who were driven to outdo, or modify, or simply copy what they saw, employing their own culture's raw material. Thus, the Jameson-Moretti law applies: local content, pertinent to each nation, was poured into forms that were adopted, with strategic alterations, from Hollywood. Where are today's hotspots? Where does cinema seem crucial and talked about?

Let's abandon the map (where necessarily one region stands front and center), and instead let's spin the globe. As it whirls, our eye intermittently catches glimpses of the shapes of the most sizeable nations. Today China and Nigeria stand out prominently alongside India and Russia. So dense are they with film activity that the globe is distended and wobbles out of true. Only sixty years ago China and Nigeria were places that had no place in World Cinema; they gained recognition only when a few promising art films found their way to the European festivals that served as image exchange centers. Today that promise has been fulfilled beyond, indeed against, expectations. Recapitulating Hollywood in its heyday Nollywood and China (Beijing/ Shanghai/Qingdao) have become thoroughly corporate and market-savvy, turning out standardized and predictable products. If fresh images are to renew World Cinema, it will hardly be from the urban image-centers. On our globalized globe, novelty should be sought on the periphery of these former peripheral nations. And indeed, exciting new work has been bubbling beyond the dense cultural centers of these nations. Independent art films and documentaries have emerged from dark corners of both places thanks to the network of festivals around the globe, but increasingly and paradoxically thanks to the rival medium of the internet, with its networks of informal distribution and what used to be called "word of mouth."
\end{abstract}




\section{Keywords}

world literature - world cinema - Hollywood - China - Nigeria

As a notion or as a field to explore, World Literature took its current shape in the 199os thanks to Franco Moretti's seductive books and articles which built toward, and then formulated, the following law of literary life: developments in fiction radiate from centers (London and Paris) to further and more distant peripheries (Spain, Italy, Russia). Later it spread to India, Japan, Latin America, and, we can add, eventually to sub-Saharan Africa. His explicitly economic "account" involves terms and concepts like literary capital, indigenous resources, cultural borrowing, accrual of interest over time, conditions of debt repayment, cultural bankruptcy, international regulation and oversight (book prizes and fairs, literary journals), the labor of functionaries (translators, agents, editors), embargoes (censorship), subsidies, and a ledger to measure quantity (number of books produced, distributed and bought, country by country or language by language) and to measure quality (prestige, and "value" accorded by media attention, universities, criticism, adaptations).

Taken as a saga of colonial expansion, Moretti's center-periphery model has been vigorously confronted by those world literature scholars who entered this field precisely to promote writing that has been, for geo-political reasons, less known and little read. ${ }^{1}$ Salman Rushdie supplied the timely war cry in the title of his 1982 article "The Empire Writes Back with a Vengeance."

Moretti hardly feels a personal affront in this reaction to his law since it operates, he would say, whether we like it or not. The 19th century novel (Moretti's expertise) moves into the mid-2oth century on the engine of publishers, librarians, translators, and others who promote and activate literature here and there. Exactly where "here and there" are to be found is the subject of world literary history, because sites of intense or innovative production tend to move around, decade to decade. Such migration, his law states, was initially from the European (anglophone-francophone) core outward to contiguous regions (the semi-periphery) and then beyond these to places where literature

\footnotetext{
$1 \quad$ Franco Moretti, "Conjectures on World Literature," New Left Review 1 (January-February 2000): 54-68.

2 Salman Rushdie, “The Empire Writes Back with a Vengeance," The Times, 3 July, 1982, 8.
} 
surely had always played a role in local experience, but where it had not done so in the world system. ${ }^{3}$

Courses on World Literature today invariably feature francophone writing, but only outside of France, and anglophone writing, but only beyond the West. Such courses do not contest Moretti's law but its consequence in relation to a corollary we might name creative entropy. Having experienced, for two centuries at least, an overproduction of novels, the West has seen an inevitable reduction in the "novelty" of any one of them. Meanwhile novelty (or creativity and value, its synonyms) is easier to spot in freshly visible places where literary activity has lain low all this time. A century ago, for example, there suddenly arose what even a French critic dubbed "The Age of the American Novel," ${ }^{4}$ to challenge both France and England. Despite Proust, Gide, Woolf, and Lawrence (Joyce appears to be a force unto himself), critics may have wearied of rummaging through the annual crop of books pouring out of the publishing industry in Paris and London, and were on the hunt for exciting new developments. They trained their eyes on the U.S. where Fitzgerald, Hemingway, Dos Passos, Caldwell, Steinbeck and especially Faulkner were inventing striking forms to articulate new experiences, year after year.

In turn, America's pre-eminence inevitably began to flatten out after wwiI. Of course formidable works continued to flow from the US, not to mention from the UK and France; however, it would be Latin America that turned the heads of readers in the 40s, 5os, and 6os: magical realism brought distinction, prestige, and various cultural benefits to an entire continent. In the subsequent decades the styles and genres of this movement, still abundant in Latin America but no longer so surprising there, started to appear in places more peripheral to the West, like the UssR, the Middle East and the Balkans. Isolated by language from the dominant discourse, this fiction was more read about than read in the West.

But in South Asia, the importation of magical realism into an already healthy, literary and anglophone culture, was volcanic. In 1981 Salman Rushdie's Midnight's Children spread swiftly across the globe, having received the Man Booker Prize as best English novel published by a Commonwealth writer that year. And so prestige descended on the distant shores of London's colonial empire. Critics scoured South Asia and other literary outposts for new writers with a magic touch, such as the Nigerian Ben Okri, whose Famished Road won the Booker in 1991. That novel, like Arundhati Roy's 1997 The God of Small Things, appeared as the progeny of Midnight's Children.

3 Moretti, "Conjectures on World Literature".

4 Claude-Edmonde Magny, L’Age du roman américain (Paris: Seuil, 1948). 
Moretti's "Conjectures on World Literature" allow for the occasional influence, like Rushdie, of the periphery on the Franco-British core, but he explicitly does not recognize the kind of South-South rapport that magical realism tempts one to see at work. Perhaps his laws of literary circulation apply less stringently in the post-colonial era (though he has shown an eagerness to press his claims to current cinema), or perhaps he might say, with Pascale Casanova, that the movement of magical realism from Latin America to the Middle East had first to go through the Soviet Union via English translations brokered in New York and London. No matter how it has occurred, the former periphery seems now fully in play in a world literary system that compromises (a favorite Moretti term) the centrality of the West.

While it follows the trajectory Moretti established in relation to the literary form that he knows so thoroughly, the bildungsroman, Magical Realism's itinerary from Cuba throughout Latin America and then across the Atlantic to India, Nigeria and beyond, relies on criteria of prestige (the Nobel for Gabriel Marquez in 1982, the Booker for Rushdie the previous year). More a sociological than an economic category, prestige is what Pascale Casanova emphasizes in her World Republic of Letters. Ever since the Renaissance prestige, she argues, has been conferred by undisputed centers of authority: Paris, London, and later New York. ${ }^{5}$ Take Rushdie. She could point out that when in 1993 Midnight's Children was selected the best novel of the previous quarter century, "the Booker of Bookers," its author was living in London, not India. And fifteen years later, when his novel was named the most important work written in English over the past 40 years, "The Best of the Booker," he could be found residing in New York. By this time South Asian novels-indeed a large spectrum of postcolonial fiction-were prominently featured in English departments across America. Such is the movement of world literature from center to periphery and back.

Just fifteen months after his broadside "Conjectures on World Literature" had helped revive The New Left Review, Moretti published in the same journal, "Planet Hollywood." A preamble recounts:

While working on nineteenth-century literary markets, I was struck by how...this looked so much like the beginning of the culture industry that

5 Pascale Casanova, The World Republic of Letters (Harvard University Press, 2004). 
it suggested a little follow-up experiment-on film markets....I began with the records published by Variety and listed the five most successful American films for every year between 1986 and 1995; then I turned to non-American markets in order to assess the extent of Hollywood's planetary diffusion. ${ }^{6}$

This text concludes with an apology for the sketchiness of the data behind its most enticing features, a map labeled "the sheer power of Hollywood."7 Moretti is explicit: the nineteenth century saw a European diffusion of Anglo-French novels; the twentieth century, a planetary diffusion of American film. And the reactions to this centralized global market? "Every discussion of cinema made outside Hollywood must begin with Hollywood," said Glauber Rocha. ${ }^{8}$ But must it also end with Hollywood? Moretti concludes:

In the case of less powerful literatures, then - which means: almost all literatures, inside and outside Europe - the import of foreign novels [and we can add, movies] doesn't just mean that people read a lot of foreign books; it also means that local writers become uncertain of how to write their own novels. Market forces shape consumption and production too; they exert a pressure on the very form of the novel, giving rise to a genuine morphology of underdevelopment. ${ }^{9}$

Although dealing with the popularity of Hollywood film since 1985, Moretti's economic vocabulary applies even better and more literally to earlier eras of cinema's international development, where the capital investments of America's banks in Hollywood studios paid off in its unrivalled international distribution arm. Even if that system stands incomplete (India's industry has been large enough since 195 o for filmmakers and audiences there to ignore Hollywood, while the PRC has never admitted many films), why deny the obvious? The Classical Hollywood model of the 1920s-195os, purveying what Miriam Hansen called a "vernacular modernism,"10 constituted an enormous core whose movies were adopted or emulated nearly everywhere (at least in the first world). Moscow may be said to form a second, smaller core, radiating a

6 Franco Moretti, "Planet Hollywood," New Left Review 9 (May-June 2001): 90-101, here go.

7 Moretti, "Planet Hollywood," go.

8 Moretti, "Planet Hollywood," 91.

9 Moretti, "Planet Hollywood," 100.

10 Miriam Hansen, "The Mass Production of the Senses: Classical Cinema as Vernacular Modernism," Modernism/modernity 6, no. 2 (April 1999): 59-77. 
different model to the nations around it, especially after wwII, but with nothing like the influence of Hollywood overall.

The astoundingly broad appeal of Hollywood's themes and its styles were guaranteed thanks to the multi-ethnicity of American cities, New York in particular. ${ }^{11}$ Having learned to entertain all classes of American spectators and a spectrum of immigrants, Hollywood producers confidently set their films before audiences anywhere in the world, especially in advanced cities where the modernity such films conveyed and purveyed could be felt incubating at a higher temperature year after year.

From the outset cinema was metropolitan. Producers needed access to financing, pools of talent, specialized equipment and laboratories one could only find in urban centers. And distributors needed concentrations of people searching for entertainment and with enough money to fill flagship theaters in major cities around the globe. In each of those cities reside ambitious writers, producers, and filmmakers, who surely sat in the front row to take notes on the most recent Hollywood imports. They then were driven to outdo, or modify, or simply copy what they saw, employing their own culture's raw material, including the faces and gestures of local actors. Thus the Jameson-Moretti law applies: local content, pertinent to each nation, was poured into forms that were adopted, with strategic alterations, from Hollywood. Classical cinema took shape in the studios of Los Angeles, but became an international medium capable of entertaining most of the people on the globe by taking up the concerns of modernity.

And most of those concerns stem from urbanization itself. Migration to burgeoning cities from towns, villages, and farms, not to mention from other countries - a phenomenon that the US experienced most intensely — brought with it unrealistic hopes and terrible anxieties. Hollywood quickly learned to represent these in all its genres. It's no wonder that in the 2os and 305 Germany and Japan ranked just behind the US in terms of number of films made and viewed, since both these countries were undergoing tremendous urban growth themselves. Alain Bergala believes that cinema feels comparatively moribund and without real consequence in the West today because the friction associated with its urban expansion has dissipated. ${ }^{12}$ Where are today's hotspots? Where does cinema seem crucial and talked about? In Iran, Turkey, Nigeria and China, where mass urbanization is still very much in process, and very much a source of social and psychological friction.

\footnotetext{
11 Miriam Hansen began to develop this idea first in Babel and Babylon, Spectatorship in American Silent Film (Harvard University Press, 1994), Chapter 1.

12 Alain Bergala, in a lecture at MICEC, Barcelona, June 2008.
} 
Now urban "concerns" are not the same as urban "themes." True, a certain number of classical movies follow themes of Lang's M, Ozu's Woman of Tokyo, or Fejos' Lonesome, but the ubiquitous modernity of Hollywood, Japanese and German films of the 20 s and 3 os is sensed in the faces, gestures, fashions, language, rhythm, sensibility, and pitch conveyed again and again in every genre (romantic comedies as much as horror movies). Vernacular modernism responds viscerally both to an entire generation's vague hopes for self-fulfillment, and to its genuine nightmares about the isolation, forbidding institutions, hypocrisy and betrayal that are rife in cities.

Like cyclones, cities gather strength by sucking in the weak who are drawn toward them; small town or village folk, immigrants from abroad, minorities with little choice, are pulled by the gravity of the dense urban core. And classical films shaped their scattered concerns into narratives with cautionary or happy conclusions, aiming to score well in key cities with such populations; then, riding critical attention and publicity, they would spin out to small towns and villages throughout America, as well as to the countries those immigrants had left.

The longevity of the Hollywood model, like anything deserving the name "classical," stems from balance, consistency, and wide appeal; nevertheless, genres, styles, and audiences evolve, requiring Hollywood to continually readjust, and leaving openings for alternative models. Cinema's evolution, like that of the novel in Moretti's view, occurs in stages, or phases, rather than as a continual progression. Moretti calls this "punctuated equilibria."13

WWII provides an obvious punctuation mark since it closed out the intense nationalism associated with the Classical era that had dominated the 1920 and 3 os. Hollywood crested in 1946 and would slide into a decline that lasted thirty years; meanwhile the modernist currents that André Bazin recognized underfoot would grow into the New Waves of Europe, Japan, and Latin America. European festivals (Cannes, Venice, Berlin and Karlovy-Vary) became more relevant than the Academy Awards, which begrudgingly offered all "foreign films" only a single prize to fight over. Paris, with its hundreds of movie theaters and numerous cine-clubs and magazines (Cahiers du Cinéma the most prominent), constituted the stock exchange where films from everywhere learned what they were worth.

Moretti's quantitative, economic model of literary circulation readily fits an idea of world cinema that Hollywood rules and will always control; in slight contrast, Pascale Casonova's cultural sociology would make Paris a cinematic as well as a literary capital of values. This doesn't mean that we need always

Franco Moretti, “More Conjectures," New Left Review 20 (April-May 2003): 73-81. 
concentrate on Hollywood's actions and Paris' reactions, but it does mean that every movement or auteur, from no matter where, needs to fight for screen space in a marketplace that Hollywood still dominates, just so that it can be discussed, if not ranked, by the critical establishment that continues to take its cue from Paris.

Let's look at things the other way around. Abandoning maps (where necessarily one region stands front and center), let's spin the globe. Even Moretti recognizes that "a single, generalizing description misses too much,"14 especially when from the outset his data allows only 46 nations, predominantly European ones, to appear (out of a possible 190). "Africa is almost entirely absent, as are ... the demographic giants of India, China and Russia." ${ }^{15}$ Giants, indeed. These areas contain 3.5 billion people, nearly half of humankind; yet in Planet Hollywood, they literally don't count. These are exactly the places we should be looking at.

To try to grasp the movement of films addressing this neglected half of the planet, I want to concentrate on the recent powerhouses, China and Nigeria. But let's glance at the USSR and India just long enough to recall their vastness and longevity. As already mentioned, Moscow did serve as an epicenter for the second world. From 1956 till at least 1974, with Hollywood at its lowest ebb, the Soviet influence was palpable in Africa and India. The first African filmmakers, still recognized as their most important, Ousmane Sembene and Souleymane Cissé, trained in Moscow, as did the French-born Angolan, Sarah Moldiror. All made revolutionary films in the first decade after decolonization. As for Indian cinema, during the 25 years after partition, most filmmakers with international reputations were Bengali and in sympathy with the socialist (even communist) ambience that prevailed in Calcutta, the nation's intellectual hub. This included the humanist Satyajit Ray, the Brechtian Ritwik Ghatak and the radical Mrinel Sen (twice on the jury of the Moscow Film Festival). However, despite a potential audience of several hundred million image-hungry Indians, their trenchant, often angry works could scarcely be amortized. Instead this audience fed on Hindi (and Tegulu and Tamil) melodramas by the

\footnotetext{
14 Moretti, "Planet Hollywood." In fact Moretti here is quoting Christopher Prendergast, "The World Republic of Letters," reprinted in Debating World Literature, ed. Christopher Prendergast (London: Verso Books, 2004), 1-26, here 25 . 
vastest entertainment film industry in the world. Moscow's influence can be seen here too, if the iconic Mother India (1958) serves as an index, for socialist realism clearly inflects its herioc style. Bombay movies, it must be noted, were wildly popular in the eastern sectors of the Soviet Union. They are still remembered in Western China as well; and no wonder, since the PRC's first decade of production exhibits the unmistakable social realist look that many Chinese directors had picked up as film students in Moscow.

Of course everything changed with — and even before-1989 with the dismemberment of the USSR, as Moscow's authority over its own directors dissolved. Russian auteurs and genre films now circulate like those from other nations in festivals and occasionally in theater chains. Russian producers routinely engage with American and European counterparts, aiming for the larger market, even while most films made in Russia are content with a sizeable national audience, together with some spillover into neighboring countries.

In the Indian subcontinent, Bombay popular cinema of the 5os, with their obligatory song and dance sequences, mutated to become the Bollywood phenomenon in the 1970s, with Sholay (1975) an unprecedented all-India blockbuster, consolidating the formula. For more than twenty years, virtually no Western film could break into the South Asian theatrical market because it was so large (8oo films produced locally each year), so self-sufficient, and expansive, that audiences had neither time nor interest in looking beyond it.

By "produced locally" I mean, made in India; however, in reality audiences and films were categorized by language (with Hindi, Telugu, and Tamil the majority). Hence, the issue of center-periphery is not just international, but exists within this nation itself even before one looks at the spread of Bollywood to Africa, south east Asia and, as we noted, northward. The expansion of Indian cinema beyond its borders seems hardly to have been preplanned until the late 199os when, no doubt spurred by VHs, then DVD packaging, Bollywood's immense diasporic audience became a factor. During the 1980s and early gos, South Asian immigrants in North America kept up with their beloved stars and trends primarily via magazines, since few actual films traveled. The most enthusiastic American filmgoer likely had never seen a film from Bombay. However, by the turn of the millennium, one could find a screen dedicated to recent Bollywood hits in the multiplex of a modest size city like New Haven Connecticut. As for metropolises like New York and Toronto, not to mention London, certain movie theaters became cultural gathering places for diasporic South Asians, some of whom thought about producing Bollywood movies involving immigrants and their experiences in Western countries. Monsoon Wedding, Bride and Prejudice, and then Slumdog Millionaire were nearly inevitable, the latter of course, directed by a Brit. 
When Global Bollywood arrived on the world stage this way, its international recognition surely spelt the end of its independence, compromising its putative difference. With one eye on the world market, producers of new Indian films to some extent displaced the nation from the center of their concern. Might (or must) such films now blend the Bollywood formula with conventions operating in world blockbusters? As for those blockbusters, although Titanic barely registered in South Asia in 1997, Avatar and other 21st century megahits finally worked their way into the entertainment diet all across India. Global entertainment works both ways.

Spinning the globe this way, our eye intermittently catches glimpses of the shapes of the most sizeable nations. Today China and Nigeria stand out prominently alongside India and Russia. So dense are they with film activity that the globe is distended and wobbles out of true. While India was a drag on cinema's vaunted universality throughout the second half of the last century, in our new century — the so-called global one-China with its 1.3 billion people and West Africa with its 700 million bulge out as unexpected and ungainly leaders in exhibition and production respectively. Highly regulated in China, not at all in Nigeria, both these overheated entertainment industries have risen literally from nothing in fifty years' time. For in 1966 the PRC had descended into its Cultural Revolution, which cut production to a trickle, actually to a few drops, while shuttering the Beijing Film Academy for a dozen years. At the very same moment West African cinema was starting from scratch. Films arrived, one nation at a time following decolonization, beginning, it is usually observed, with Ousmane Sembene's 1965 La Noire de. from Senegal. The four features he turned out in the next ten years effectively constituted what the world knew of African cinema. ${ }^{16}$

It is one thing for films to be produced, another thing for them to be screened, and have an influence on local audiences or on World Cinema. Without any distribution system, those few African films made each year would have languished in invisibility, were it not for the biannual pan-African festival (FESPACO) held in Ouagadougou, Burkina Faso. In 1969, its initial

16 A few score other African features were made this first decade, including Djibril Mambety's new-wavish Touki Bouki which, aside from a screening at the 1973 Moscow Festival, would only be known, even within its native Senegal, twenty years later. There were also a couple African films made in Paris, like Med Hondo's Soleil O, shown at Cannes in 1970 with a small release in France and New York. 
year, only 23 shorts and features were screened, amounting to practically the entire continent's fiction film production over the past decade. It took a decade for FESPACO to take hold and for a small but steady stream of films to fill its program. The first prizewinner with a name recognizable today came in 1979, Soulymane Cissé's Baara. That year the number of films screened grew to nearly a hundred (meaning around fifty features were produced per year throughout the continent, including North Africa).

Always a convenient way to measure trends, film festivals do much more in the case of emerging cinemas like those of China and Africa, for they visibly affect those trends, thanks to the criticism, distribution deals, and connections that directly result in the visibility — the availability—as well as the reputation of films that would otherwise go unseen. How else could such films come to light, given that ambitious local works have seldom played on the few theaters in those places, where, moreover, not many foreigners travelled who might bring back news of the cinema there. In Africa it was up to FESPACO to build an audience of African artists, intellectuals and entrepreneurs, who sadly otherwise would not have seen films from their own continent; this spurred new films and trends which attracted an increasing number of international critics as well as scouts from international festivals, prepared to pick off films that struck them as significant. The results are manifest in the 8 os and early gos when African films could be anticipated at many festivals and were being shown regularly at museums, universities, and cultural centers in cities on every continent.

However, this heyday clouded over as the millennium approached. Festivals lost some of their taste for the exoticism that many African movies naturally provide. The millennial generation of francophone African auteurs led by Mahamet-Saleh Haroun and Aberdhamane Sissako, turned mournful in their inaugural works, Bye-Bye Africa and La Vie sur terre (1999). Both films open with the filmmakers, playing themselves, returning from Paris to their Pays natale, Chad and Mali respectively. They each find an Africa in need of aid just to sustain life. Haroun finds something even more distressing to him: the devastation of the movie theaters where his childhood hopes had been sparked. Today's young men now hang out at video clubs, unconcerned that the image they squint at is both small and degraded. As Bye-Bye Africa concludes, the central character, Haroun himself, spurns a producer who offers to underwrite a film shot on a camcorder. Unable to raise financing to complete even his small $35 \mathrm{~m}$ essay-film, he leaves Chad, bequeathing his camera and a flicker of hope to a young boy.

That hope was not vain, for Haroun would soon recover from this disillusion, making the beautiful Abouna in 2003, followed by a suite of well-regarded 
works. And Sissako has become a beloved and familiar name in France and the USA after his powerful Bamako and Timbuktu, the latter nominated for an Academy Award. Still, neither filmmaker represents Africa in the way Sembene, Cissé and Idrissa Ouédraogo had done before the video era. Haroun was rightly distressed at the sight of those vendors of Nigerian videos. His native Chad produces at best one film every other year, while across the river in Nigeria, two to three videofilms are added each day to the market. Eventually such an avalanche smothers the thoughtful, critical cinemas struggling to make a difference at FESPACO and beyond.

The fact is that for over a quarter century, despite their number, Nigerian films did not play at festivals because movies there had been shot and distributed exclusively on video formats that were unprojectable in theaters, at least till 2012. I learned about this phenomenon in 1995 and read what I could, but there was little to view at the time. In an overview of African cinema written in 1999, I concluded:

Today in Nigeria and Ghana entrepreneurs shoot videos with camcorders in Igbo, Haussa, and especially Yoruba languages for the direct-to-video market. ${ }^{17}$ A completely decentered system of production, video-films largely bypass centers of exhibition as well. These images are never projected at festivals, and are scarcely exported. Indeed they are not made for big screens (which, dangerous to attend in Lagos and other cities, are being transformed into churches one by one). Nevertheless, their popular success in these densely populated countries and their miniscule budgets, have made these video-films the first commercially successful motion picture movement in Africa. Whereas throughout its history Nigeria had produced fewer than two hundred features in $35 \mathrm{~mm}$, more than five hundred video films have been made in the past three and a half years. ${ }^{18}$ Speculators in Ghana, a country without any feature film heritage, turned out more than fifty of these in 1993 alone. ${ }^{19}$

Such wildcat production boomed once distributors realized that they could easily sell tapes in the city markets in addition to renting halls with

17 At the time I wrote this, most of my information regarding Nigerian video-films had come from Onookome Okome who lectured at the University of Iowa in April 1997. See his co-authored contribution in Jonathan Haynes, ed., Nigerian Video Films (Ibadan: Kraft Books, 1997). He and Haynes have since published and edited comprehensive studies.

18 These statistics can be found in Afolabi Adesanya, "From Film to Video" in Nigerian Video Films, 37-50.

19 Esi Sutherland-Addy, "The Ghanaian Feature Video Phenomenon," unpublished paper, Accra, 1996. 
video-projectors for a paying audience. They find a huge public through billboard advertising of new-born stars, through radio and TV spots, and through word of mouth, still the strongest source of information in Africa. A traditional system of debts and favors has kept costs low, for actors appear in each others' films free, just to pay off an earlier reciprocal favor. Such alliances and filiations in production, and the exploitation of open and black markets, and of ancient trading routes in distribution (especially to Yoruba villages) make video-films an unbelievably disorganized yet overheated enterprise. Of course, what appears disorganized to the state (which does manage to exact a censorship fee in most cases) or to any centralized view of culture, appears intricately coordinated in a Deleuzean economy. These images seem to come up through the cracks in the culture. Mostly uncatalogued and unlisted, they spread and multiply wherever they find room. Western critics may never know or care to know what they look like. Effectively self-generating and unauthored, they could be classified as events or behavior more than as texts. They do not solicit scholars like me or like Deleuze, but circulate in apparent randomness in West Africa. They do not stand up for themselves like Baobab films; nor do they reach to an international audience like the Afro-pop movies. So far they have succeeded in bypassing us altogether. These "movies-that-are-missing," circulating outside our discourse, are significant in being so insignificant to us. Expanding so fast into "the Open" that it cannot be tracked, the vigor rather than the beauty or wisdom of this image life attests to a force that philosophy and criticism can only stand hopelessly in awe of. ${ }^{20}$

This report might have been debatable even in 1999, but just a dozen years later it had become well out-of-date. Production had zoomed to 1500 films a year and scholars had descended on Lagos and Kano to be the first to trumpet all the activity there. Nigerian videos followed the African diaspora and could be found in stores in London, New York, Toronto, even New Haven. Cable stations in many countries started to play them. There was still little talk of their aesthetic value or their contribution to the development of film style. At a conference in Amherst Massachusetts in 2006, the activist Tunisian cineaste, Nadia El Fani, felt ashamed that her films came from the same continent as such trashy images. Although the following year a Nigerian film, Ezra, finally

20 Dudley Andrew, "The Roots of the Nomadic: Deleuze and the Cinema of West Africa," in G. Flaxman, The Brain is the Screen: Deleuze and the Philosophy of Cinema (Univ. of Minnesota Press, 2000) 244-245. 
was acclaimed at FESPACO, it turns out to have been sponsored by the French TV conglomerate ARTE with significant American financing because of its topic, the abduction of a child into soldiery. Thus the Nigerian phenomenon has attracted far more anthropological discussion than aesthetic description or speculation. Anthropology is exactly what Brian Larkin pursued in his excellent Signal and Noise which analyzes the phenomenon of Haussa video-films, uncovering a vast visual culture and economy in Kano. Symptomatically, the two key films he does delve into were impossible to access until very recently when one of them, Glamour Girls (1994) was uploaded to YouTube from an old vHs.

Nollywood's size and immense local popular appeal has drawn to it scholars who used to focus on the francophone sector of critical art films, (the FEsPACo fare). While this shift in focus may appear opportunistic, academics drawn to Nigeria by the gravitational force of its massive output have arrived just in time to track a demonstrable improvement in overall technical quality in the industry as well as the beginnings of higher aesthetic ambition in certain works. Although it will be a long while before any such films are likely to compete with the beauty and complexity of Sissako's work (or any of the best FESPACO examples, such as Tey, the 2007 winner from Senegal), larger budgets have encouraged a few producers to aim to release their films on a few of the 200 screens newly built in the multiplexes of Lagos and other cities. Such films then could command higher prices when sold to cable channels or on DVD. And as the films improve, multiplexes will likely devote more screens to local fare rather than to Hollywood or Bollywood. ${ }^{21}$

Nowadays the budget of a couple Nigerian titles each year can reach the \$10o,ooo level, and reputable South Asian cameramen have been hired. Lighting is more subtle in these works, and many special-effects are no longer obvious fabrications. In short, aesthetic values are necessarily on the rise just so that Television Companies, theater owners and ordinary viewers can discriminate among styles, genres, and directors, choosing what they find attractive from the immense pool of what is otherwise indiscriminately available. Something like "criticism" has had to develop, just to assist programmers in the burgeoning cable market to choose which hundred or so of those 1500 films to broadcast in a given year.

21 My information comes from "New Directions in Nollywood and Nigerian Cinema," a conference organized by Brian Larkin and Awam Amkpa at Columbia University, April 22 2016. In the past few years things have changed even further. The conference talks and speakers can be found at https://www.ias.columbia.edu/event/nollywood-conference. 
Meanwhile, cable stations have become part of corporate sponsorship of Nigerian productions. "Africa Magic" runs eight channels dedicated to Nollywood; others are administered by "iROKOtv," a company large enough to have acquired Netflix for Africa;22 "StarTimes," a third media conglomerate, this one from China, entered the market in 2015. With budgets and aesthetics rising together this way, Nollywood indeed appears similar to Hollywood.... not today's Hollywood, but Hollywood in its first decade. From 1912-1922, hundreds of American films brought about a culture of stars whose faces and allure were advertised, exactly as has happened in Nigeria. Following on stars, such names as Griffith, Tourneur, and Ince became revered by producers and critics. Studios provided consistency of casts and crews, usually channeling these into genres for easier production and marketing. Thus Nollywood may recapitulate the birth of the classical cinema, doing so in a new century and on a new continent.

There is no avoiding it: two completely different "ideas of African cinema" exist side by side. Once these might have been labelled respectively Francophone and Anglophone, identifying the opposing cinematic heritages left behind by the colonizers of the countries involved. However, I prefer center and periphery. Even its name makes Nollywood a centralized phenomenon, a genuine industry in the making. On the other hand, the films that find their way to FESPACO, are "assembled" (in the Deleuzian sense) as isolated productions, their nomadic directors gathering what they need from here and there. There may have been a moment just after Apartheid ended, when Souleymane Cissé expressed what turned out to be a vain hope that Johannesburg could become the financial and industrial rock upon which a consistent and important continental African cinema could be built. He produced Waati in 1995, as an allegory he thought might prime the pump. But Waati's financing was primarily arranged among French companies. And the trajectory of its plot (from South Africa to Cote d'Ivoire to central Mali and back again) might stand as an emblem of the nomadic idea of cinema.

Cissé and other strong African directors travel with their films to festivals, museums, and universities where they briefly take the limelight, instigating discussion of African art and politics, if only for an evening. Their films are fragile, peripheral, yet memorable. The titles coming out of Nollywood, on the other hand, seldom register with critics who focus instead on the sociology of genres and trends, and on the business deals and models which move forward

22 Netflix has subsequently become a major investor in Nollywood, helping larger productions to skirt DVD piracy through its streaming service. 
ineluctably, like a rising tide. ${ }^{23}$ It is a mark of our era that, where African cinema is concerned, attention has turned to the quantity (of films and viewers and of money invested or made) and away from the quality of art and critique embodied in individual works.

China

Star Times, which controls close to 500 channels across Africa, has become a key Chinese investor in Nollywood. Its goal is explicit: to import certain of the African films they license to reach a niche audience in Asia. For, given China's population and its 43,000 screens, even a small niche is economically significant. Still, in the context of Chinese entertainment business, Nollywood will always be of peripheral interest, a minor enterprise, despite far out-producing China in terms of films. In the movie business, however, scale is measured not by the number (or certainly quality) of films made, but by economics, that is by assets and investments. In 2016 Nigeria could boast 200 screens in fifty multiplexes while China has over 40,0oo screens. Now surpassing the US in domestic box office receipts, China already reaps revenues from theaters in the US and around the world after Wanda purchased AMC Entertainment, becoming the largest owner of theaters anywhere. True, Nollywood's revenue is not easy to track, most of it coming from video copies and from cable TV. But with a population eight times that of Nigeria, and with its three largest internet providers actively involved in film distribution and increasingly in film production, China rightly sees itself as a supernova. Its gravitational force aims to pull American producers and stars to the outskirts of Qingdao, where one of the largest, and best-equipped production complexes anywhere opened in 2018.

Surprisingly and disappointingly, a great many scholars concerned with Chinese cinema have been sucked into the vortex this juggernaut has created. Articles, books, and courses parade its economic strength and the size of its home audience. But what about the films being produced for that audience, films that soon, we are told, will be marketed globally? We could focus on a single title, The Great Wall (2016) since it is emblematic of the entire situation. Produced in Qingdao by a consortium of companies led by Legendary East and China Film Group, but including Hollywood financing too, its $\$ 150$,ooo, ooo

23 The most thorough study to date of the entire phenomenon carries a telling title: Jonathan Haynes, Nollywood: the Creation of Nigerian Film Genres (Bloomington: Indiana University Press, 2016). 
budget could scarcely be amortized by domestic box office returns, since that would have required that 40 million Chinese buy tickets (estimating an average ticket at $\$ 5$ ). To lure one of every thirty Chinese citizens to the theater, enormous publicity was mobilized and an inordinate number of screens requisitioned. Still, this, like any blockbuster, needed to garner much of its revenue from abroad, where exceptional promotion was planned. The Great Wall was meant to be a spearhead, opening the world's theaters to subsequent films, many of them to be co-productions, organized and shot in China. ${ }^{24}$

Matt Damon, Willem Dafoe and Andy Lau were cast in The Great Wall to attract such an inclusive audience. ${ }^{25}$ Unsurprisingly Zhang Yimou directed it; after all, his opening Olympic ceremony at the BirdsNest enjoyed a budget and an audience at least three times greater than that of this film. As its title makes plain, the theme of The Great Wall, keeping the dangerous "other" at bay and protecting civilization, further establishes the centrism that Zhang Yimou has promoted at least since Hero, the epic about the success of the Han empire to establish a central seat of power. Needless to say, The Great Wall played at no film festivals. It didn't need such exposure or promotion, as it sits in the center of what is now being referred to as Huallywood. ${ }^{26}$

And yet, ironically, Zhang Yimou's own career depended on his peripheral status, and in several senses of that term. In the first place, because of the ongoing consequences of the Cultural Revolution, his first films, like any Chinese offerings that reached the rest of the world in the 1980s, were by definition peripheral. Second, those films that were instantly recognized came from the outlying studios of Xian and Guangxi, which took chances by drafting brilliant young graduates of the Beijing Film Academy's 5 th, generation. ${ }^{27}$ Zhang Yimou, Chen Kaige, and Tian Zhuangzhuang found themselves luckily sent far from Beijing and its bureaucratic oversight. Under the umbrella of sympathetic studio heads, and without being required to satisfy Chinese exhibitors, they realized the aesthetic ideas inspired by their schooling. Third, manifestly those ideas flourished in their initial works, generally set before

24 Although Імдв reports its US boxoffice at $\$ 45$ million and its world gross at $\$ 345$, о0о, no followup Chinese films have yet saturated the world's screens like this.

25 See Amy Qin, "Hollywood Courts China on Two Fronts," New York Times, January 22, 2017, Arts \& Leisure, 11 .

26 See Jinghua Yuan, "Hua and Huallywood: Reflections on the Naming Development of Chinese Cinemas," paper presented at "Chinese Cinema, to and Beyond Hollywood," April 15, 2016, Yale University.

27 The PRC established fourteen studios, several of which were in Beijing and a couple in Shanghai. Others were scattered. By the end of the 1980s each studio was to produce about ten features a year without considering their potential. 
the 1949 Communist takeover and in remote parts of China often involving non-Han peoples. A painterly treatment of dramatic landscapes and an exotic anthropological exploration of "primitive" rituals and customs set these films against the rest of China's output. This cost the fifth generation films much local distribution, as they were shunted aside either as ideologically heterodox or as simply uninteresting. On the other hand, these very qualities gained them an international audience hungry for new styles and for a peek at anything that might be remote or forbidding.

The dozen years from 1981-1993 found filmmakers in many "peripheral" places feeding this cinephilic hunger through a "return to sources," (said of the West Africans) or "root-searching" (said of the Chinese). Claiming ties to their own pre-modern, non-western cultural pasts, filmmakers could heroically throw off official or classical constraints, letting native aesthetic impulses inspire radical cinematic techniques. In Senegal, Burkina Faso and Mali, Safi Faye, Gaston Kaboré, and Souleymane Cissé, reversed the relation of filmmaker to subject. Rather than gathering Africa's people and problems into their scripts and studios to be exposed by the gaze of their analytical cameras, these filmmakers felt called to go out to the villages and submit themselves to oral and animist ways of representing landscape, society, history, and morality. Festivals snapped up the best of these as mysteriously beautiful and as strikingly distinct from Western models. Yeelen's 1987 triumph at Cannes only increased the appetite and sponsorship of "deeply African images" supplied, for example, by the genius Djibril Mambety in his 1993 Hyenas and by Idrissa Ouédraogo in four village canticles including Tilai, which beat out Zhang Yimou's root-seeking Ju Dou for the Grand Jury Prize at Cannes in 1990.

Among the eighteen films in competition at Cannes that year, Tilai and $J u$ Dou satisfied Festival tastes for extraordinary landscapes, pre-modern rituals, bizarre family relations (and transgressions), in an atmosphere of scarcely concealed eroticism. Rey Chow has warned of the West's attraction to China's masochistic self-exposure, using $J u$ Dou as a prime example. ${ }^{28}$ She might equally have pointed to the Yugoslavian Time of the Gypsies (1987) where Emir Kusturica channeled the raw energy of a Rom village to propel his magical realism. Yugoslavia, it should be noted, sits on Europe's eastern periphery. On Europe's other periphery, rural Ireland, Jim Sheridan turned to local gypsies ("traveling people" in actuality) to upend conventions in The Field (also 1990) and Into the West (1992).

28 Rey Chow, Primitive Passions: Visuality, Sexuality, Ethnography, and Contemporary Chinese Cinema (New York: Columbia University Press, 1995). 
Wherever it appears, "Cultural Nationalism" like this is authorized to ignore standard script-writing rules; it often pretends to ignore writing altogether by dipping into the oral traditions of pre-modern peoples. Yugoslavian epics, African griots, and Irish song and poetry promised to expand cinema's possibilities. Similarly, New Zealand cinema reached the world stage in 1993 under a diluted indigenous aesthetic in The Piano and Once were Warriors. Reacting to the articulate Heritage genre which in France and Britain had been proudly ventriloquizing sanctioned novels and historical tomes, these upstart "cultural nationalist" works are meant to sound crude and guttural. Instead of white-gloved culture, they put their hands in the fertile mud of untamed landscapes, extracting extraordinary images. Their exposure, side by side, at Festivals ratified the idea that cinema is an international artform, each nation distinct but equal when seen together on screens at Toronto or Rotterdam, and soon sitting side by side on the shelves of video stores.

African and Chinese cinemas came boldly into prominence under these conditions. The timing was perfect, for the European artfilm was "in the doldrums," Serge Daney judged in $1981 .^{29} \mathrm{He}$ and the festivals (which, starting in 1975, included Montreal, Toronto and Hong Kong) scouted the edges of far-off film cultures for new alternatives to a resurgent Hollywood clogging the world's screens with Star Wars and its progeny. Daney, having himself traveled to India and Africa, encouraged Olivier Assayas, then a critic at Cahiers du Cinéma, to explore his fascination with Asia. Assayas went to Hong Kong on assignment to attend the festival of 1983 , where he ran into a treasure of films ignored in the West. Since the Hong Kong festival always screens films from the city's past, Assayas and Charles Tesson were able to quickly gain a sense of its history through catalogs as well as screenings. They assembled a legendary special issue of Cahiers du Cinéma (March 1985) that introduced the Hong Kong aesthetic. A weeklong series of Hong Kong hits was immediately programmed at the famous Studio des Ursulines in Paris bringing a new source of exciting movies onto the radar screens of French cinephiles.

Next up would be New Taiwanese cinema, which Assayas learned about in Hong Kong through critic (and future director) Chen Kuo Fu. ${ }^{30}$ Assayas flew to Taipei to look for himself and met Hou Hsiao-hsien who, he immediately

29 Serge Daney, La rampe: Cahiers critique 1970-1982 (Paris: Cahiers du Cinéma, 1983), 157.

30 Cindy Ying-Huk Wong, Film Festivals: Culture People, Power on the Global Screen (Piscataway: Rutgers University Press, 2011), 204. Wong notes that no Taiwanese film played in the festival till 1987 when Edward Yang's The Terrorizers opened the event. Still, in these years the festival made sure that personalities from the PRC and from Taiwan, like Zhang Yimou and Hou Hsiao-hsien, made contact with each other. They would also meet at Locarno and other festivals whenever their films were simultaneously selected. 
realized, was spearheading a movement he found to be an authentic inheritor of The French New Wave. ${ }^{31}$ Assayas' reports from Asia did not include the PRC. In any case, he wouldn't have run into any PRC films in 1983 in Hong Kong, for it was only after the Cahiers issue that Yellow Earth broke through there. ${ }^{32}$

And what a breakthrough! Writing of Chinese art cinema, Tony Rayns doesn't equivocate: “It would be tempting to put an exact date to its birth, April 12,1985 . That was the evening when Yellow Earth played to a packed house at the Hong Kong International Film Festival....The screening was received with something like collective rapture. And the post-film discussion stretched well past its limit." ${ }^{\prime 3} \mathrm{~A}$ few months later it captured the audience and the prize at the Hawaii International festival where I happened to be in attendance. Watching it in a small screening room alongside its director and his cameraman, none other than Zhang Yimou, (anonymous in their jeans jackets and Mao caps), I was knocked off balance by the film's look and tone. Gene Siskel was also present, taking full notes. Yellow Earth would rank high on the list he and Roger Ebert established for the year. Soon cinephiles everywhere knew these names, as did programmers at festivals like Locarno, Venice and Cork Ireland where, along with Tian Zhuangzhuang and others of the fifth generation, they would regularly be invited.

In fact PRC films had trickled into Cannes as early as 1981 with an adaptation of a Lu Xun story. In 1983 Xie Jin's The Herdsman was shown in "Un Certain Regard," a wing of Cannes established in 1978 to expand the festival's offerings beyond standard aesthetic norms. "Un Certain Regard" would screen Xie Fei's Girl from Hunan in 1987. By then things had progressed to the point where Yeelen, with its profoundly African aesthetic, not only was selected to participate in the main competition but took the Jury Prize. In 1990 Ju Dou was the first film from the PRC entered in the Cannes competition, ${ }^{34}$ opening the door

$3^{1}$ See Assayas' acclaimed documentary, A Portrait of Hou Hsiao-hsien, (Cineastes de notre temps, 1999).

32 It wasn't just the French who brought Chinese films to the attention of the West. Marco Müller, a peripatetic programmer brought a first glimpse of Hong Kong films to the venerable, though tiny, Mostra di Pesaro as well as to the brand-new Torino Festival in 1982 and 1983. He was the one who brought Yellow Earth to Locarno, setting it off against Hou Hsiao-Hsien's My Summer with Grandpa (Dongdong de jiaqi), so European audiences could taste the differences and similarities between the earliest of the New Taiwanese and fifth generation films. Locarno would maintain its Asian orientation, especially after Müller took over as director in 1992. See Wong, Film Festivals: Culture People, Power on the Global Screen, 48.

33 Tony Rayns recounts this in Wong, Film Festivals: Culture People, Power on the Global Screen, 212.

34 The previous year Zhang Yimou's inaugural film, Red Sorghum (Hong gaoliang), took the Silver Bear at Berlin. 
for Chen Kaige, whose Farewell My Concubine won the Palme d'Or three years later. But by this time Chen may have been playing directly to what he knew the festivals prized, while calculating what he felt the Chinese government might permit and audiences everywhere might desire. ${ }^{35}$ Straddling the West and China in the 1990s, Chen aimed for the most advantageous ratio among the "four key concepts" that Zhang Yimou candidly outlined in 2014:

The market decides everybody's thoughts. Today, many Chinese directors talk about box office and business. It is completely different from the time when we made Red Sorghum. We didn't even mention business and box office. We talked only about politics and art. Now we are still talking about politics and art, but also we talk about business and box office. This is the biggest difference... [As] directors, we always prefer talking about art more. It is a matter of balance. Now the factors affecting the balance have increased. In the past there were two words. Now there are four words. ${ }^{36}$

The contradiction embedded in the term "balance" directly identifies the shift from periphery to center, that is, from art and politics (the 1980s) to business and box office (the present day). Whereas Zhang and other fifth generation directors once balanced art and politics, skirting or suffering censorship while often engaging in or artfully masking critique, today he balances balance itself against what was then simply the negotiation of art and politics, since the market force of business (production) and box office (exhibition) was not pertinent when he began his career. Art and politics, exactly the focus of the vibrant discussion inaugurated by Chinese films of from 1985-1993, is clearly peripheral to the centrality of business and box-office today, the topics that film scholars, not just journalists, have rushed to explore.

Several of Zhang's films of the 199os exhibit the increasing importance of the center even when the periphery remains the focus of concern and sympathy. The heroine of The Story of Qiu Ju (1992) arrives in the city as an outraged villager trekking there for redress. And the young rural heroine of

35 Farewell My Concubine (Bawang bieji) was reluctantly released in China, with cuts, because international outrage greeted the ban that had originally been imposed on it for its treatment of the Cultural Revolution. The controversy undoubtedly contributed to the dynamic popular and critical response it received in the PRC. See Patrick E. Tyler, "China's Censors Issue a Warning," The New York Times, September 4, 1993.

36 Clifford Coonan, "Director Zhang Yimou Talks Chinese Box Office, 'Coming Home' and the Upcoming 'Great Wall' (Q\&A)," The Hollywood Reporter, July 24, 2014, < https://www. hollywoodreporter.com/news/director-q-a-zhang-yimou-721134>, accessed April 19, 2014. 
Not One Less (1997) finds herself drawn to the metropolis and its central TV station to solve her quandary, meanwhile drawing the attention and largesse of the center to neglected areas beyond its usual reach. Evidently educational reform in the countryside, when supported by the city, should produce proper citizens, thus expanding the perimeter of the State. In Going Home (1999) Zhang maps the reverse movement as a city-center businessman, returning to his northern village, preserves the customs he remembers as a child, since otherwise these would expire. Thus the center benevolently respects the traditions that preceded it and in some sense still nourish it, just as Zhang Yimou pays tribute to his early years as an outlier in the system, since they prepared him for his role as China's (indeed the world's) most powerful State impresario.

Today in West Africa as well as China two ideas of cinema stand starkly opposed, visible in two scales of films. In upscaling from small budgets to the largest ever expended anywhere, Zhang's reputation as an artist has fallen. But (to switch to the other meaning of this homonym) the scales were tipped in the mid-gos under the weight of money at stake for filmmakers in China's refashioned economy. Suddenly, the system of values went from two terms to four - and "not one less." Assessing the worth of Chinese productions - the "produce" displayed and then weighed in Beijing's or Hollywood's Central Markets - scholars who once interpreted the art and politics of Chinese films have had to learn, and perhaps to appreciate, the abacus of business and box office.

Even if we accept that the Central market dominates Chinese cinema today, resistance remains. Ironically, this dominance was initially challenged by what became known as "The Urban Generation." The Troubleshooters led the way even before the Tiananmen incident; then came Beijing Bastards, Beijing Bicycle, Postman and other underground works that surprised the Rotterdam or Thessaloniki festivals. Jia Zhangke's Xiao Wu, a winner in 1997 at Berlin, Nantes, and Pusan, was followed by Platform confirming him as China's new star. Among cinephiles at home and abroad, he was said to replace Zhang Yimou with whom he was bound to spar, especially after the Golden Lion at Venice went to his Still Life in 2006, then opened in Beijing the same day as Zhang's Curse of the Golden Flower. Dressed ornately in its \$50,000,ooo budget and with the State distribution machine behind it, Curse commanded the key theaters in the capital, shoving Jia's difficult film (made at a fifth the cost) to a 
few houses in Beijing's outskirts. Jia cried "foul," fomenting resistance to such "authority of Power." 37

Against "authority of power," Jia Zhangke stands as an auteur. He stands among the fourteen filmmakers given a chapter each in a recent anthology, The Global Auteur: the Politics of Authorship in 21st Century Cinema. Beside him stands the Mauritanian, Sissako, the dates and extent of whose fame correspond to Jia's. While both directors intuitively and ingeniously find ways to represent previously invisible corners of China and West Africa, respectively, they address the entire globe. International funding and critical reception confirm this standing, as do the prodigious allegories each brought to life in Shijie (The World, 2004) and Bamako (2006). Globalization struts in both films, unmasked by the enormity of its effects on the pitiable characters whom it strangles. Jia puts it grotesquely on display as a World Theme Park just outside Beijing; while for Sissako globalization takes the form of The World Bank, literally put on trial in a courtyard somewhere in Mali's bustling capital city. Sissako followed with Timbuktu, a masterpiece like Jia's Still Life, both conjuring, with Dantesque imagery, two human-made catastrophes that have descended this century on beleaguered, displaced peoples. Still Life witnesses the wanton destruction of entire towns lost to the logic of the 3 Gorges energy project, while Timbuktu follows its uncomprehending subjects as they fail to avoid the onslaught of militant Islam coming to occupy and dismantle one of civilization's most revered cities.

The West may righteously think it is doing China and Africa a favor in paying attention to these auteurs from its periphery, but today it is we who need them, we who depend on the images, stories, and critiques they engender. Each has made good on the artistic investments of the two generations of filmmakers who preceded them in their homelands until, in peering into and through the problems of those lands, they implicate and address us all.

Who is listening to this address, and how is it heard? Bamako made just over $\$ 100,000$ in the US, playing on but a single screen (except for one week when it played on four);38 Still Life made half that amount, also on one screen in New York. But both had wide festival exposure, where, thanks to the journalists always present there, remains the surest filter to help those who care about the future of the art to locate what is new and valuable. Many of us predictably

37 Ira Jaffe, Slow Movies: Countering the Cinema of Action (London and New York: Wallflower Press, 2014), 149.

38 Timbuktu grossed over a million dollars and found itself at one point on fifty American screens. It also brought in over a million French viewers. It was aided by its topicality, plus nomination for Best Foreign Film at the Oscars. 
read the French press and follow those films that reach screens in Paris, as this has always been the most welcoming city for "the foreign." Where else would you look? Surely not in China itself since distribution and critical response there is an unreliable index.

In 2016 two films with remarkable surface similarities presented themselves in Paris: Red Amnesia (Chuang ru zhe, 2014) and Kaili Blues (Lu Bian Ye Can, 2015). Both feature older characters who are shocked into revisiting a past misdemeanor, the guilt for which they have managed to suppress. Both leave their homes to travel to the place where they were put in a morally compromised situation (by happenstance, the Province of Guizhou). ${ }^{39}$ Seen side-by-side, they provide a lesson in the evolution of the language of cinema, taking quite different paths in their effort to solve an enduring narrative problem: how the past may emerge into the present. Growing to maturity as Proust was writing his Recherche and as Bergson was still theorizing the interpenetration of past and present, cinema has been experimenting for a century with solutions to this aesthetic problem and opportunity.

Its international title tips Red Amnesia toward what might be called public memory. The crime that is ultimately exposed goes back to the Cultural Revolution, and specifically the Third Front period, when Mao moved many factories out of major cities to far off places like Guizhou as a preemptive defense against a possible attack by the Soviet Union. When the threat subsided, a certain percentage of those displaced were lucky enough to be permitted to return to the capital. This is the case for Deng Menzhui, then in her 2os, who forged her family's name on the permit meant for her friend and neighbor, thus jumping ahead in line. In the intervening fifty years her family prospered in Beijing, while the other family, left behind, languished as the factory and its community deteriorated. Early on we are shown a teenager who harasses Mrs. Deng by making anonymous phone calls, tossing a brick through her window, dumping garbage on her son's front door and stalking her. The film breaks its indicative tense with the occasional appearance of the ghost of Mrs. Deng's recently deceased husband, called up, as it were, when she talks to him as if talking to herself. He sits at meals with her, including once when she has a guest at table (her teenage nemesis in fact) who is baffled when she addresses someone he can't see. Vague presentiments gradually make her suspect that these attacks on someone as elderly as she cannot be random, but are retribution for that act she committed a half-century ago. Dreams and visions of the past, the most arresting moments in the film, bring her to visit Guizhou and

39 See Jiwei Xiao and Dudley Andrew, "Poetics and the Periphery: the Journey of Kaili Blues" Cineaste online, June 2019. 
the factory-town that now seems like an archeological ruin. In the decrepit rooms of a block home, she finds her hostile former friend and realizes that she is the mother of her nemesis. The director, Wang Xiaoshuai, never lets the mystery overrun its effects on Mrs. Deng who is, after all, a living representative of a resurgent China needing to recognize the harm suffered by innocent people in Mao's day, harm that persists. The sage introduction of the past into the routine of present day Beijing lifts Wang's work above his first 6th generation films like Beijing Bicycle, by adding a temporal and moral dimension to everyday life in China.

Though sophisticated and ambitious enough to play at Venice, Toronto, and Busan and to be picked up for French distribution after a good run in the PRC, Red Amnesia looks traditional in the way its "sheets of past" (pace Deleuze) are layered above and below observational scenes of daily life. The transitions between layers have none of the cleverness of, say, Hou Hsiao-hsien's Good Men Good Women, where compromising fragments from the heroine's own diary mysteriously arrive by Fax in her apartment. Red Amnesia is more straightforward, deploying, rather than advancing, the standard language of cinema. Tzvetan Todorov would label its unsettling effect "uncanny," a mystery that is ultimately unveiled if not rectified. ${ }^{40}$

Kaili Blues, on the other hand, is a genuine work of "The Fantastic," marking a leap in film language, and not just in the Chinese cinema sphere. ${ }^{41}$ Its baffling yet seductive weave of past and present takes on the character of a phenomenology of guilt, screening the itinerary of a purely private consciousness. Once the hero, a middle-aged doctor, decides to leave the city of Kaili to visit the mountain village of Zhenyuan, where years back he was marginally yet lethally involved in a gangland murder, the temporal status of the images becomes illegible. Its hero's visitations with the past are difficult to place, difficult even to see. A train crossing the screen diagonally in superimposition takes him and us into an indeterminate zone. Motifs and characters appear according to the train's rhythm it seems, not chronologically. Clocks are shown to run backwards. When the doctor reaches the village, halfway into the film, the camera is literally unleashed as it traces (or forges) a network of relations among people, activities, places and modes of transportation (boat, motorcycle, truck). This tour-de-force 45-minute shot across two sides of a river, and through a nest of streets, puts a half dozen characters into contact by relay. The camera sometimes outguesses the action, darting alone through

40 Tzvetan Todorov, The Fantastic (Ithaca: Cornell University Press, 1975), 44ff.

41 For a full analysis of the film see Jiwei Xiao and Dudley Andrew, "'Poetics and the Periphery: the Journey of Kaili Blues" Cineaste online, June 2019. 
an alley to intercept a speeding motorbike, thus catching up with its driver. Poetry voiced to the side of the image track follows associational logic, until we accept the film not as a representation but as the experience of a haunting. "The fantastic," conjured by sightings of a creature called "The Wild Man," takes the film into territory associated with Apichatpong Weerasethakul (Tropical Malady, Uncle Boonmee, Cemetery of Splendor). In such works, all from the post-colonial spaces that Pheng Cheah claims hold a particular spell over World literature and film, the spirit-past seeps through geology into the organized space of the political present. ${ }^{42}$

However neither artistic prowess nor poetry amounts to power. "I'm a marginal," Bi Gan says, "And all the categories drawn up to define filmmakers come from the Beijing Film Academy. I'm far from such institutions." Yet he won the "Forward Future Award" at the 2016 Beijing International Festival, propelling him to his more commercially viable second feature, Long Day's Journey into Night. For the moment Bi Gan stands up tall enough on the edges of the map of Chinese Cinema to attract cinephiles and festivals searching for distinctive quests that further what cinema can accomplish through stylistic invention, and hoping to find an oblique perspective on life in a country centered in Beijing and Shanghai.

Joining him as Chinese marginals whose peculiar narratives are set on the country's edges are Pema Tsedan from Tibet, and the Korean-Chinese auteur, Zhang Lu. Their latest works, which contain almost no spoken Mandarin, are nevertheless Chinese entries getting warm receptions at the Berlin and Venice festivals. Importantly, both are published writers, Pema Tseden writing in both Mandarin and Tibetan, and shuttling between an apartment in Beijing and his home in Katmandu.

In following the course of cinema in China and West Africa, this essay has likewise shuttled between and within these nations to locate cineastes who continue to exploit the endemically mobile and unstable nature of a medium whose art seems by nature peripheral.

Distinctive visions of film and of society still survive beyond the dense cultural centers of their nations. They have done so not just thanks to the network of festivals around the globe, but increasingly and paradoxically thanks to the

42 Pheng Cheah, What is a World?: On Postcolonial Literature as World Literature (Duke University Press, 2016). 
apparently rival medium of the internet, with its networks of informal distribution and what used to be called "word of mouth." In the case of China, the very internet giants that have their hand in production as well as distribution, make possible, as a side effect to be sure, the survival of unmarketable Chinese art films that are so peripheral as not to register...except on the (radar) screens of those who point their antennae away from the neon and noise of the gaudy entertainment capitals. 